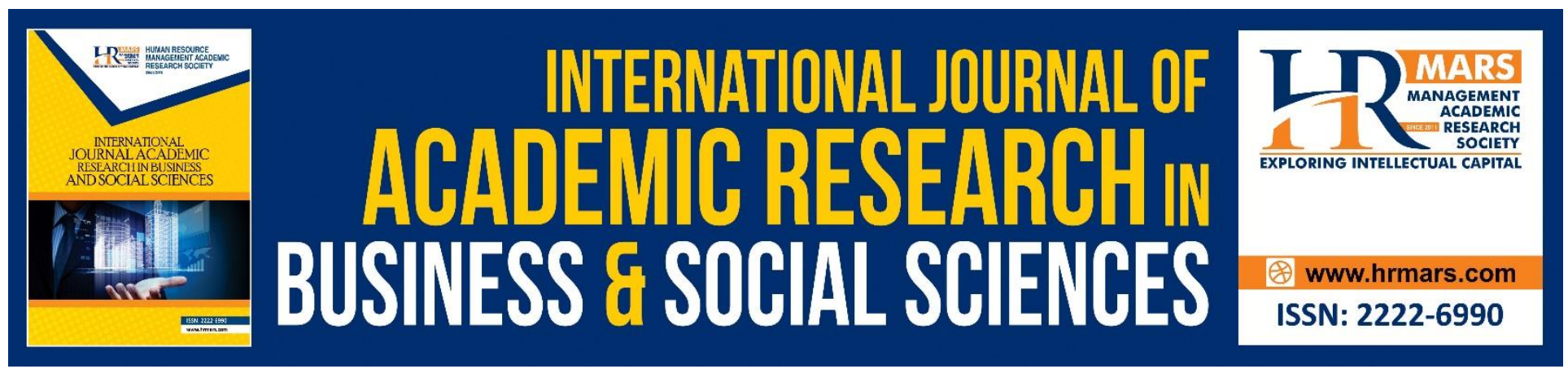

\title{
Financial Development and Economic Growth in Tanzania: An Empirical Investigation
}

Mnaku Honest Maganya

To Link this Article: http://dx.doi.org/10.6007/IJARBSS/v8-i8/4470

DOI: $\quad 10.6007 /$ IJARBSS/v8-i8/4470

Received: 04 July 2018, Revised: 22 July 2018, Accepted: 29 July 2018

Published Online: 21 August 2018

In-Text Citation: (Maganya, 2018)

To Cite this Article: Maganya, M. H. (2018). Financial Development and Economic Growth in Tanzania: An Empirical Investigation. International Journal of Academic Research in Business and Social Sciences, 8(8), 291-307.

Copyright: (C) 2018 The Author(s)

Published by Human Resource Management Academic Research Society (www.hrmars.com)

This article is published under the Creative Commons Attribution (CC BY 4.0) license. Anyone may reproduce, distribute, translate and create derivative works of this article (for both commercial and non-commercial purposes), subject to full attribution to the original publication and authors. The full terms of this license may be seen at: http://creativecommons.org/licences/by/4.0/legalcode

Vol. 8, No. 8, August 2018, Pg. 291 - 307

Full Terms \& Conditions of access and use can be found at http://hrmars.com/index.php/pages/detail/publication-ethics 


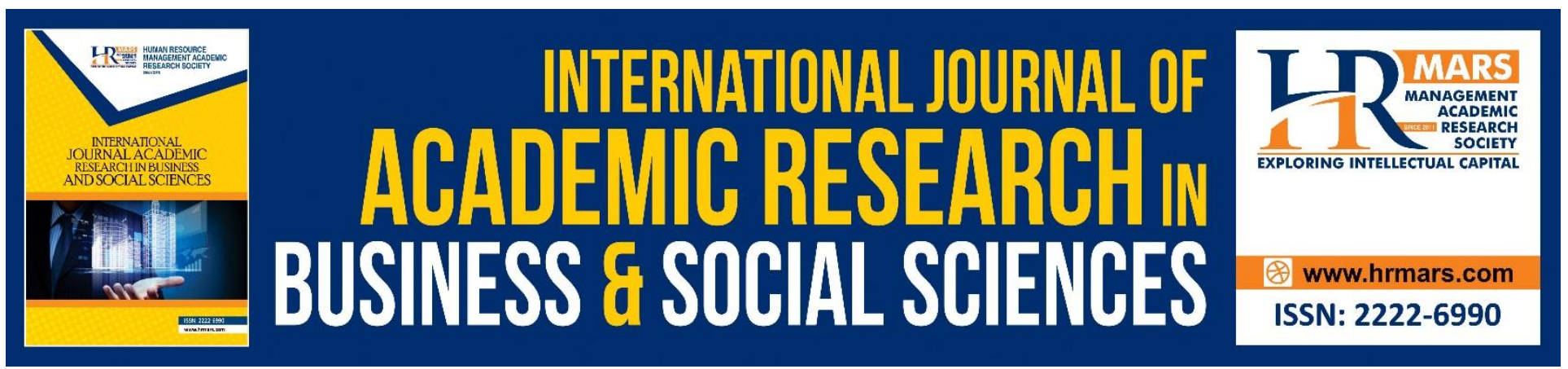

\title{
Financial Development and Economic Growth in Tanzania: An Empirical Investigation
}

\author{
Mnaku Honest Maganya, PhD \\ Lecturer, Institute of Finance Management (IFM), Dar es Salaam, Tanzania \\ Email: mmaganya@hotmail.com
}

\begin{abstract}
Tanzania economy like of many other emerging market have seen rapid increase number of banks locally and foreign owned since financial sector liberalization in 1990's even though clear impact of financial sector on economic growth is hard to be singled out. The paper investigates empirically the long run relationship between selected proxies of financial development and economic growth in the Tanzanian context. Using the vector error correction model (VECM), the study finds that financial development is cointegrated with economic growth. That is there is a long run relationship between chosen proxies of financial development and economic growth in the country. This paper used broad money supply M2, foreign direct investment, customer deposits in foreign and domestic banks, credit extended by foreign and domestic banks as percentage of GDP as proxies for financial development. While per capita growth rate used to measure economic growth. The results also show the need to develop even further the financial sector through appropriate regulatory and macroeconomic policies in order to ensure sustainable economic growth as well as economic development. For robustness of the results other test were also performed in this study such as Augmented-Dickey Fuller unit root test and Johansen cointegration test.
\end{abstract}

Keywords: Economic Growth, Vector Error Correction Model, Broad Money, Foreign Direct Investment, Gross Domestic Product

\section{Introduction}

One of the significant destinations of many macroeconomic strategies around the world is economic growth. This provides the crucial means of elevating expectations for living a standards life, as well as accomplishing economic development and reducing poverty in a society. Economic growth has been defined by economic experts from numerous perspectives. Generally, a number of economists see economic growth as a rise in the domestic production or the level of income of different economic agents in a country over a specific period. Moreover, economic growth is characterized as an expansion in countries' productive capacity. Consequently, gross domestic product (GDP) is being considered by many scholars as proxy of economic growth (Vazakidis and Adamopouslos, 2009). 
From empirical point of view it is perfectly clear that countries that have strong monetary and financial system tend to build up its economic growth and economic development all more rapidly. Financial institutions is a standout amongst the most basic organizations everywhere around the world as banks in particular assume principal role in the economy of a nation, where they provide financial assistance to both public and private sectors, however at the same time this sector also faces incapacity because of non-performing loans and failed in recovery of given advances. In finance standings performance of the financial institutions means profitability and liquidity in economic exercises. If it happens that, say profitability of the bank is increasing continuously overtime it implies that bank performance is growing. On the other hand, the solvency of the bank means capability to encounter its short-term and long-term liabilities, if the bank is in the solid solvency situation it states the bank performance is well and good (Akpansung and Babalola, 2012). There is no suspicion that the provision of money to local and foreign investors in both primary and secondary financial markets, attempting to prepare these markets both in terms of prices and sizes, as it adds to an effective contribution to the creation of new sustainable economic projects and extension of the prevailing projects, which indicates support the economy for the better represented by increasing the standard of living, and raised per capita GDP and income of corporations and returns for the government through direct and indirect taxes, as well of reducing the unemployment rates through employing new workers in the new projects initiated.

In the real world phenomena the financial sector provides and facilitates sustainable environment for the economy to thrive in economic growth. It act as financial intermediaries between surplus spenders (savers) and deficit spenders (borrowers) in stimulating economic activities of the country through provision of loans, deposits, capital, and exchange of currency for imports and exports and provide markets for economic agents which are the producers, consumers, government, and investors. It follows therefore, in support of Joseph Schumpeter view that the financial system and financial intermediation can promote economic growth. For the country to realize economic growth, efficient and effective functioning of financial systems supported by sound monetary and fiscal policy is a crucial issue (Schumpeter, 1911)

In Africa, as far as issue of finance-growth nexus is concern, just like elsewhere around the globe, there is also no consensus regarding the direction of causality between financial development and economic growth. For instance, Agbetsiafia (2004) studying seven African countries, found mostly unidirectional causality running from financial development to economic growth thus lending support for the supply leading phenomena of the finance-growth nexus. Ghirmay (2004) also found that financial development played a causal role in the economic growth of eight out of the thirteen Sub-Saharan African (hereafter, SSA) countries he investigated empirically. Using three proxies of financial development, Atindehou and colleagues (2005) found weak causal relationship in almost all the twelve West African countries they studied. Studying three SSA countries, Odhiambo (2007) also finds conflicting results where the demand following was supported in Kenya and South Africa while in Tanzania the supply-leading response was supported. Abu-Bader and Abu-Qarn (2008) investigated the case of Egypt, Morocco and Tunisia, using four different proxies of financial development, found a bi-directional causality running between financial development and economic growth. In contrast, Baliamoune-Lutz (2008) finds mixed results for North African countries in the finance-growth nexus. Akinlo and Egbetunde (2010) using panel data techniques investigates 10 SSA countries, the results show that financial development Granger causes economic growth in Nigeria, Central African 
INTERNATIONAL JOURNAL OF ACADEMIC RESEARCH IN BUSINESS AND SOCIAL SCIENCES

Vol. 8, No. 8, August 2018, E-ISSN: 2222-6990 @ 2018 HRMARS

Republic, Congo Republic, and Gabon, while economic growth Granger causes financial development in Zambia. However, bidirectional relationship between financial development and economic growth was found in Swaziland, Kenya, Chad, South Africa, and Sierra Leone. While the different methodologies used to study the finance-growth connection in developed as well as developing countries have distinct strengths and weaknesses, they produce remarkably consistent results. The main, tentative conclusions that we learn from most recent empirical work is that countries with a better-developed financial system tend to grow faster in comparison. Specifically, financial institutions that act as both financial intermediaries and markets matter for growth. The size of the banking system and the liquidity of stock markets are each positively linked with economic growth (Zivengwa et al., 2011).

This paper intends to investigate empirically impact of financial development on economic growth in Tanzanian context using Vector Error Correction Model. Specifically, the study tries to investigate whether improvement in financial sector leads to economic growth in Tanzania. This paper draws inspiration from the growing contention that investigation into finance-growth nexus should be narrowed down to country-specific, time series studies which provide the opportunity to account for country-specific economic conditions (King and Revine, 1993; Bittencourt, 2012; Adusei, 2012). The study is of policy and academic relevance for two reasons. Firstly, it is expected that a country specific study for Tanzania using novel econometric tools would generate evidence which is not only robust but also capable of informing economic policy for sustainable economic growth and developments. The argument here is that if national economic policy is to favor a supply-leading experiment in the form of financial restructuring program, it is imperative that policy makers are able to isolate the relevant financial variables in the economy based on robustly-tested empirical evidence. Secondly, despite the vast interest in the finance-growth nexus worldwide as stated above, research in this area remains scanty on Eastern Africa. The findings of this study will hence add to the much needed literature on this subject on Tanzania and the East African region in general.

\section{Literature Review}

In principle, it is commonly accepted that financial development is a concept with multidimensional features and comprises a predominantly crucial role for short-run and long-run economic growth of the country. There are number of studies that support the relationship between financial development and economic growth, both theoretically and empirically (Levine, 2003; Goodhart, 2004; Liang and Teng, 2006; Baltagi et al., 2009; Abu-Bader and Abu-Qarn, 2008; Esso, 2010; Ndako, 2010). The theoretical foundation of this economic growth growth-financial development relationship (hereafter EG-FD relationship) can be traced back to the work of Schumpeter (1911). Three outlooks regarding the potential importance of finance in economic growth has been presented by existing literature. While the first one considers finance as a critical element of growth (Schumpeter, 1911; Goldsmith, 1969; McKinnon, 1973; Shaw, 1973; Odhiambo, 2009), finance is regarded as a relatively negligible factor in growth according to second opinion (Robinson, 1952; Lucas, 1988; Stern, 1989; Quartey and Prah, 2008). Finally third observation thinks of on the potential negative impact of finance on growth (Van Wijnbergen, 1983; Buffie, 1984; Rioja and Valev, 2004; Arcand et al., 2012).

From theoretical point of view, development of financial sector and economic growth are commonly regarded as being positively related. However, based on the findings of extensive empirical 
INTERNATIONAL JOURNAL OF ACADEMIC RESEARCH IN BUSINESS AND SOCIAL SCIENCES

Vol. 8, No. 8, August 2018, E-ISSN: 2222-6990 @ 2018 HRMARS

investigation, this theoretical assumption remains ambiguous (Levine, 2005; Shen and Lee, 2006; and Kar et al., 2011; Adusei, 2013). Following reviewing of the relevant empirical literature, it has been has indicated that there have been growing concerns and controversies on providing a conclusive results regarding the EG-FD relation. The empirical results from the literature have indicated that the EG-FD relation could be positive, negative, or neutral (Xu, 2000; Zang and Kim, 2007; Tran, 2008; Donwa, and Odia, 2010; Akpansung and Babalola, 2012). This different outcome of the empirical investigation is attributed to the utilization of different proxies for financial development and economic growth in developed as well as developing countries. (e.g Ben Naceur et al., 2008; Eita and Jordaan, 2010; Brasoveanul et al., 2010; Ayadi et al., 2013; Adusei, 2013). In the literature, the positive EG-FD relation has been illustrated by as follows, a large size of capital market positively related with the ability to mobilize capital and diversify risk on an economy-wide basis (Nowbutsing, 2009). Furthermore, the value of stock traded in the market should positively reflect liquidity in the whole economy. Financial institutions through financial intermediaries play an effective role in directing scarce financial resources to potential investment that, positively, promotes future economic growth; this is from the banking sector side. Levine and Zervos (1998) in their seminar paper they used panel data from 47 countries over the period 1976-1993. They concluded that stock market liquidity and banking sector development in those selected countries are positively and significantly correlated to current and future economic growth.

As it has been mentioned above, the existing literature offers a wide range of perspectives and insights into the issue of the growth-finance nexus, whereby sometimes report contradicting empirical results. It has been argued by Bagehot (1873) and Hicks (1969) that financial system played a critical role in igniting industrialization process in England simply by facilitating the mobilization of capital for investments. Schumpeter (1934) emphasized the crucial need of financial system in growth of the economy and pointed out situations when financial institutions, particularly banks can actively encourage innovation and future growth by identifying and funding efficiency and productive investments. The relationship between financial development and economic growth has been an important issue of debate, with the contributions of McKinnon (1973) and Shaw (1973) and during the last fifty years this relationship has been extensively studied. Not only old literatures, but also recent empirical studies offers contradictory evidence on finance-growth nexus (Naceur and Ghazouani 2007; Ang, 2008; Jalil et al., 2010; Wu et al., 2010; Odhiambo, 2010; Kar et al., 2011;Rousseau and Wachtel, 2011; Arcand et al., 2012; Al-Malkawi et al., 2012; Pradhan et al., 2013; Menyah et al., 2014). Consequently, due to the observed contradictory empirical evidence, the current verdict on the relationship between financial sector development and economic growth and their causality has remained inconclusive. However, most of the discussion focuses on measures of financial sector development, which requires most authors only to analyze an approach that uses the same database published by the common International Financial Institutions (for cross sectional studies). Accordingly, it is logical to find almost the same results. Furthermore, what might be an adequate financial system at one time or in one institutional, social and economic environment may be outright detrimental at another time or in other perceived environments. In other words, there may be various structural shifts or breaks which further complicate identification of causal relationships between finance and growth (Herwartz and Walle, 2014).

Conversely to the traditional approach to analyze the finance-growth relationship, Graff (2005) proposed an alternative approach to the traditional work, to assess the level of financial sector 
INTERNATIONAL JOURNAL OF ACADEMIC RESEARCH IN BUSINESS AND SOCIAL SCIENCES

Vol. 8, No. 8, August 2018, E-ISSN: 2222-6990 @ 2018 HRMARS

development, for the banking sector inputs and its impact on performance of economic growth. The new approach introduced is based on Graff resources available for development of the banking system and can be summarized in three indicators: the share of manpower employed in the banking system, the banking system's share in GDP and the number of banks and branches per capita.

\section{Data and Methodology}

Data Type and Sources

In this paper for the purpose of data analysis, end of year reports from BOT mainly those released by Directorates of Banking Supervision, Economic Reviews reports by National Bureau of Statistics, IMF reports, World Bank reports is used as secondary data sources. Selected banks audited financial statements will be used to fill the gaps of data that will not be obtained from BOT, World Bank, IMF and NBS reports. These are basically second source of information which provides secondary data.

Economic growth is being measured as the growth of Real GDP per capita to represent dependent or endogenous variable in this particular study. In summary proxies that were employed as the measure of financial developments as independent or exogenous variables are being categorized as follows:

a. M2/GDP that measure ratio of Broad Money (M2) to GDP.

b. DCP/GDP that measure by the ratio of Domestic Credit to private sector to GDP. For better analysis of results DCP will be divided to DCP1/GDP for Domestic banks Credit to private sector and DCP2/GDP for Foreign banks Credit to private sector.

c. BD/GDP that measure the ratio of Bank Deposit to GDP. Banks deposits will also be categorized into foreign and domestic banks.

It is believed that other variables that have not been included in this study, could have great impact on economic growth and that their omission could bias the direction of causality between financial development and economic growth in the country. In view of this, one control variable is being included: share of FDI to GDP in order to avoid simultaneous bias in the regressions model (Gujarati, 2009).

\section{Multivariate Cointegration Analysis and Error Correction Modeling}

Since from econometrics paper, the cointegration and error correction methodology is well explained and well documented all together (Engle and Granger 1987, Johansen 1988; Johansen and Juselius 1990; Banerjee, et al., 1993; Cavaliere, et al., 2007) here only a brief overview is being provided. Johansen (1988) multivariate cointegration model is based on the error correction representation given by:

$$
\Delta X_{t}=\mu+\sum_{i=1}^{\rho-1} \theta_{i} \Delta X_{t-i}+\phi X_{t-1}+\varepsilon_{t}
$$

Where $X_{t}$ is an $(n x 1)$ column vector of $\rho$ variables, $\mu$ is an $(n x 1)$ vector of constant terms, $\theta$ and $\phi$ represent coefficient matrices, $\Delta$ is a difference operator, and $\varepsilon_{t} \sim N(0, \Sigma)$. The coefficient matrix $\phi$ is known as the impact matrix, and it contains information about the long-run relationships. Johansen's methodology requires the estimation of the VAR equation 1 and the residuals are then used to compute two likelihood ratio (LR) test statistics that can be used in the determination of the unique cointegrating vectors of $X_{t}$. The cointegrating rank can be tested with two statistics: the trace test and the maximal eigenvalue test. 
INTERNATIONAL JOURNAL OF ACADEMIC RESEARCH IN BUSINESS AND SOCIAL SCIENCES

Vol. 8, No. 8, August 2018, E-ISSN: 2222-6990 @ 2018 HRMARS

\section{Vector Error Correction Model (VECM)}

The error correction version pertaining to the variables incorporated in our study is stated below:

$$
\begin{aligned}
& \Delta G D P_{t}=\delta_{0}+\sum_{i=1}^{n} \delta_{1 i} \Delta G D P_{t-i}+\sum_{i=1}^{n} \delta_{2 i} \Delta F_{t-i}+\sum_{i-1}^{n} \delta_{3 i} \Delta K_{t-i}+\lambda_{1} E C M_{t-1}+\varepsilon_{t} \\
& \Delta F_{t}=\beta_{0}+\sum_{i=1}^{n} \beta_{1 i} \Delta F_{t-i}+\sum_{i=1}^{n} \beta_{2 i} \Delta G D P_{t-i}+\sum_{i=1}^{n} \beta_{3 i} \Delta K_{t-i}+\lambda_{1} E C M_{t-1}+\varepsilon_{t}
\end{aligned}
$$

Where $E C M_{t-1}$ is the error correction term and $\varepsilon_{t}$ is the mutually uncorrelated white noise residual. The coefficient of the $E C M$ variable contains information about whether the past values of variables affect the current values of the variables under study. The size and statistical significance of the coefficient of the error correction term in each ECM model, measures the tendencies of each variable to return to the equilibrium. A significant coefficient implies that past equilibrium errors play a role in determining the current outcomes. The short run dynamics are captured through the individual coefficients of the difference terms. Variable representing proxies of Financial development $\left(\mathrm{F}_{\mathrm{t}}\right)$ does not Granger cause economic growth (GDP) if all $\delta_{2 i}=0$, and economic growth (GDP) does not Granger cause financial development $\left(F_{t}\right)$ if all $\beta_{2 i}=0 \gamma 2 \mathrm{i}=0$. These hypotheses can be tested using standard F statistics (Andrei and Liviu, 2015)

\section{Results and Discussions}

\section{Descriptive Statistics}

Table 1 below summarizes descriptive statistics of data that were used in the study. The Table of descriptive statistics shows small standard deviation values, this suggest that natural logarithms of selected variables are not dispersed significantly from their mean values which can also be supplemented by small deviations between minimum and maximum values. Medium values are very close to the mean values for natural logarithms of all variables, however, its important also to note that natural logarithm of data that were corrected by diving proxies of financial development by nominal GDP might also produce negative values as such they should be interpreted with cautions.

Table 1: Descriptive Statistics

\begin{tabular}{|l|l|l|l|c|c|c|c|}
\hline & Mean & Median & Min & Max & Std Dev & Kurtosis & Skewness \\
\hline LnRGDP & 13.593 & 13.502 & 13.078 & 14.270 & 0.430 & -0.688 & 0.691 \\
\hline Ln(FDI/GDP) & -3.088 & -3.010 & -3.683 & 2.605 & 0.365 & -0.511 & -0.577 \\
\hline Ln(M2/GDP) & -1.331 & -1.337 & -1.417 & -1.250 & 0.058 & -0.003 & 0.418 \\
\hline Ln(DF/GDP) & -2.918 & -2.941 & -3.152 & -2.660 & 0.053 & 0.026 & 0.251 \\
\hline Ln(CDD/GDP) & -2.140 & -2.137 & -2.240 & -2.020 & 0.068 & 0.012 & 0.022 \\
\hline Ln(CPF/GDP) & -3.429 & -3.442 & -3.586 & -3.180 & 0.138 & -0.008 & 0.819 \\
\hline Ln(CPD/GDP) & -2.732 & -2.662 & -3.113 & -2.210 & 0.166 & 4.880 & -2.218 \\
\hline
\end{tabular}

The skewness is a symmetry in a statistical distribution, in which the curve appear distorted as either skewed to the left or right. The skewness for a normal distribution is zero; this implies therefore any symmetric data should have skewness near zero. The skewness of In(FDI/GDP) and In(CPD/GDP) are negative indicating that the data is skewed to the left, which means that the left tail is long relative to the right tail. The kurtosis measures sharpness of the peak of the frequency distribution. The 
INTERNATIONAL JOURNAL OF ACADEMIC RESEARCH IN BUSINESS AND SOCIAL SCIENCES Vol. 8, No. 8, August 2018, E-ISSN: 2222-6990 @ 2018 HRMARS

kurtosis of all variables except $\ln (\mathrm{CPD} / \mathrm{GDP})$ are less than three, indicating that data have few outliers compared to the ones expected from normal distribution. Distribution with kurtosis of greater than three are said to be leptokurtic.

\section{The Unit Root Test}

Most of the time series data such as the ones used in this study tend to exhibit either a determistic and/or stochastic time trend and are therefore found to be non-stationary; that is, the variables in question have, means, variances and covariances that are not time invariant. The direct application of Ordinary Least Square (OLS) to non-stationary data produces regressions that are misspecified or spurious in nature (Engle and Granger, 1987). Consequently, variables were tested for a unit root using an Augmented Dickey-Fuller test (ADF). The results of the stationarity tests at level show that some of the variables have a unit root. Having found that the variables are not stationary at level, the next step is to difference the variables once in order to perform stationarity tests on difference variables (Dickey-Fuller, 1981). The results of the stationarity tests on differenced variables confirmed stationarity. The ADF test results are being presented in Table 2 suggests that at the $1 \%$ and $5 \%$ significant levels we cannot reject the null hypothesis for any variable except $\ln (\mathrm{CPD} / \mathrm{GDP})$, which means that the unit root problem exist to all variables except $\ln (\mathrm{CPD} / \mathrm{GDP})$ and $\ln (\mathrm{CPF} / \mathrm{GDP})$ at level with $10 \%$ significance level. As it has been shown that some of the variables are not stationery hence violate the basic assumption of the classic linear regression model. According to this assumption variables should have a constant mean, variance and the covariance between the two time periods should be zero. Violation of this assumption leads to spurious regression. Spurious regression is a regression that provides misleading statistical evidence of a linear relationship between independent non-stationary variables. To avoid this short fall, the unit root test was conducted at levels and first difference of variables in order to ensure that all variables are stationary before running regression.

Table 2: Unit Root Test Results

\begin{tabular}{|l|c|c|c|c|}
\hline \multirow{2}{*}{ Variable } & \multicolumn{2}{|c|}{ Levels } & \multicolumn{2}{c|}{ First Difference } \\
\cline { 2 - 5 } & $\begin{array}{l}\text { ADF test } \\
\text { statistics } \\
\text { (Intercept) }\end{array}$ & $\begin{array}{l}\text { ADF } \\
\text { statistics (Trend } \\
\text { and Intercept) }\end{array}$ & $\begin{array}{l}\text { ADF test statistic } \\
\text { (Intercept) }\end{array}$ & $\begin{array}{l}\text { ADF } \\
\text { statistics (Trend } \\
\text { and Intercept) }\end{array}$ \\
\hline LnRGDP & 0.427 & -1.384 & -1.037 & -2.410 \\
\hline Ln(M2/GDP) & 1.899 & -0.006 & -1.036 & -1.881 \\
\hline Ln(FDI/GDP) & -2.566 & -2.373 & -4.135 & -5.391 \\
\hline Ln(DD/GDP) & -1.995 & -1.608 & -2.476 & -2.955 \\
\hline Ln(DF/GDP) & -0.860 & -2.434 & -3.547 & -3.052 \\
\hline Ln(CPD/GDP) & -7.405 & -4.295 & -1.443 & -1.955 \\
\hline Ln(CPF/GDP) & -2.838 & -2.746 & -3.475 & -2.666 \\
\hline
\end{tabular}

\begin{tabular}{|l|c|c|c|}
\hline Critical Values & $\mathbf{1 \%}$ & $\mathbf{5 \%}$ & $\mathbf{1 0 \%}$ \\
\hline Intercepts & -3.75 & -3.00 & -2.63 \\
\hline Trend and Intercepts & -4.38 & -3.6 & -3.24 \\
\hline
\end{tabular}

The Augmented Dickey-Fuller test was conducted with trend and without trend. The ADF test results are shown in Table 2 above; from the table it's clear that unit root problem exist at levels for all 
INTERNATIONAL JOURNAL OF ACADEMIC RESEARCH IN BUSINESS AND SOCIAL SCIENCES Vol. 8, No. 8, August 2018, E-ISSN: 2222-6990 @ 2018 HRMARS

variables except In(CPD/GDP) which have absolute $Z$ values for intercept, trend and intercept 7.405 and 4.295 respectively which are higher compared to critical values at $1 \%, 5 \%$ and $10 \%$ level of significance. Taking first difference $\ln (\mathrm{FDI} / \mathrm{GDP})$ appear to be stationary at all levels of significance while $\ln (D F / G D P)$ and $\ln (C P F / G D P)$ are stationary at its intercept with $10 \%$ confidence interval.

\section{Cointegration Test}

Having confirmed that all variables included in the regression model are integrated of order one, the next step is to test for the existence of a cointegration relationship among the variable series using the Johansen-Juselius approach as described in the methodology section. The cointegration test results for all variables of interest in the study are reported in the Tables below. Johansen tests results indicate that all variables are cointegrated with growth of real GDP, that is, all variables have longrun linear relationship with growth of real GDP per capita.

Table 3: Johansen Cointegration Test for GDP growth and Broad Money Supply

\begin{tabular}{|l|l|c|l|c|}
\hline & \multicolumn{3}{|c|}{ Unrestricted Cointegration Rank test (Trace) } \\
\hline Hypothesized No of CE(s) & LL & Eigen Value & Trace statistics & $5 \%$ critical value \\
\hline None & 22.681 & - & 194.454 & 15.41 \\
\hline At most 1 & 119.900 & 2 & & \\
\hline At most 2 & 119.908 & 0.00305 & & \\
\hline
\end{tabular}

Table 4: Johansen Cointegration Test for GDP growth and FDI

\begin{tabular}{|l|c|c|c|c|}
\hline & \multicolumn{3}{|c|}{ Unrestricted Cointegration Rank test (Maximum Eigen Value) } \\
\hline Hypothesized No of CE(s) & LL & Eigen Value & Max Eigen Value & $5 \%$ critical value \\
\hline None & - & - & 14.07 & 3.76 \\
\hline At most 1 & - & 1 & 4.78 & \\
\hline At most 2 & - & 0.54945 & & \\
\hline
\end{tabular}

Table 5: Johansen Cointegration Test for GDP growth and Customer Deposits in Foreign Banks

\begin{tabular}{|l|c|c|c|c|}
\hline & \multicolumn{4}{|c|}{ Unrestricted Cointegration Rank test (Trace) } \\
\hline Hypothesized No of CE(s) & LL & Eigen Value & Trace statistics & $5 \%$ critical value \\
\hline None & 9.7398 & - & 217.6348 & 15.41 \\
\hline At most 1 & 113.7119 & 1 & 9.6907 & 3.76 \\
\hline At most 2 & 118.557 & 0.80113 & & \\
\hline
\end{tabular}

Table 6: Johansen Cointegration Test for GDP growth and Customer Deposits in Domestic Banks

\begin{tabular}{|l|c|c|c|c|}
\hline & \multicolumn{4}{|c|}{ Unrestricted Cointegration Rank test (Maximum Eigen Value) } \\
\hline Hypothesized No of CE(s) & LL & Eigen Value & Max Eigen Value & $5 \%$ critical value \\
\hline None & - & - & - & 14.07 \\
\hline At most 1 & - & 1 & 1.8887 & 3.76 \\
\hline At most 2 & - & 0.27006 & & \\
\hline
\end{tabular}


INTERNATIONAL JOURNAL OF ACADEMIC RESEARCH IN BUSINESS AND SOCIAL SCIENCES Vol. 8, No. 8, August 2018, E-ISSN: 2222-6990 @ 2018 HRMARS

Table 7: Johansen Cointegration Test for GDP growth and Credit to Private Sector by Foreign Banks

\begin{tabular}{|l|c|c|c|c|}
\hline & \multicolumn{4}{|c|}{ Unrestricted Cointegration Rank test (Trace) } \\
\hline Hypothesized No of CE(s) & LL & Eigen Value & Trace statistics & $5 \%$ critical value \\
\hline None & 9.0715 & - & 213.1696 & 15.41 \\
\hline At most 1 & 114.4536 & 1 & 23.1666 & 3.76 \\
\hline At most 2 & -115.6563 & 0.33028 & & \\
\hline
\end{tabular}

Table 8: Johansen Cointegration Test for GDP growth and Credit to Private sector by Domestic Banks

\begin{tabular}{|l|c|c|c|c|}
\hline & \multicolumn{4}{|c|}{ Unrestricted Cointegration Rank test (Maximum Eigen Value) } \\
\hline Hypothesized No of CE(s) & LL & Eigen Value & Max Eigen Value & $5 \%$ critical value \\
\hline None & - & - & - & 15.41 \\
\hline At most 1 & - & 1 & 7.0301 & 3.76 \\
\hline At most 2 & - & 0.69016 & & \\
\hline
\end{tabular}

\section{Estimation of the Vector Error Correction Model (VECM)}

As it has been shown before, estimating a regression model with non-stationary variables could lead to spurious regression. To solve for stationarity, the variables are first differenced and then short-run relationship is estimated. However, estimating a model with first differenced variables leads to loss of long-run information. Therefore, an error correction model is used to bridge both short-run and long-run relationship within the context of a single equation.

Consequently, this paper estimated the impact of financial development on economic growth in the context of the Vector Error Correction Model in Tanzania. The variables used to capture domestic banks contribution are credit to private sector and customer deposits share of to GDP by domestic banks. Variables that capture foreign banks contribution are credit to private sector and customer deposits ratios to GDP by foreign banks, other financial variables such as broad money supply percentage share to GDP and foreign direct investment percentage share to GDP were also included so as to test their influence on GDP growth, while the variable used to capture economic growth is real GDP per capita growth.

Before estimating the model, the optimal lag length of each variable in the model was determined in order to ensure that the model is well specified. Final Prediction Error (FPE), the Akaike Information criterion (AIC), Hannan and Quinn Information Criterion (HQIC) and the Schwartz Bayesian Information Criterion (SBIC) were used to determine the optimal lag length. Ultimately, the optimal lag length were selected basing on which lag was mostly selected by four criteria. Table 9 below summarizes test results of lag selection criteria.

Table 9: Optimal Lag Selection Test Results

\begin{tabular}{|l|c|c|c|c|c|}
\hline Variables & Lags & FPE & AIC & HQIC & SBIC \\
\hline LnRGDP & 2 & -0.0410 & -0.5426 & -1.1715 & -0.3331 \\
\hline $\operatorname{Ln}(\mathrm{M} 2 / G D P)$ & 0 & 0.0021 & 0.0022 & $-3.5113^{*}$ & 0.0022 \\
\hline $\operatorname{Ln}(F D I / G D P)$ & 1 & 0.0348 & 0.5683 & -0.9875 & -0.7245 \\
\hline $\operatorname{Ln}(\mathrm{DD} / G D P)$ & 0 & 0.0061 & -2.2643 & -2.4740 & -2.3424 \\
\hline $\operatorname{Ln}(\mathrm{DF} / G D P)$ & 0 & 0.0138 & -1.4509 & -1.6606 & -1.5290 \\
\hline $\operatorname{Ln}(\mathrm{CPF} / G D P)$ & 3 & $0.0017^{*}$ & -4.1608 & -4.9994 & -4.4732 \\
\hline $\operatorname{Ln}(\mathrm{CDP} / G D P)$ & 0 & 0.00004 & -7.3004 & $-7.5101^{*}$ & -7.3786 \\
\hline
\end{tabular}


INTERNATIONAL JOURNAL OF ACADEMIC RESEARCH IN BUSINESS AND SOCIAL SCIENCES Vol. 8, No. 8, August 2018, E-ISSN: 2222-6990 @ 2018 HRMARS

NB: * Criteria that did not choose selected Lag

Table 10 below shows the results of VEC model when lagged in one period, and error correction term is included for every variable. All variables except broad money supply to GDP ratio (M2/GDP) lagged to one period have positive significant impact on GDP growth. Share of broad money supply to GDP found to have a significant negative impact on growth rate of per capita GDP in the economy. The short run dynamics are captured by the individual parameters except that of the ECM term.

Table 10: Vector Error Correction Model Test Results

\begin{tabular}{|l|l|c|c|c|c|}
\hline \multicolumn{2}{|c|}{ Variable } & Coefficient & Std Error & t-statistic & P-Value \\
\hline \multirow{2}{*}{$\Delta \ln R G D P_{\mathrm{t}-1}$} & $\mathrm{~L} 1$ & 0.2473 & 0.9128 & 1.13 & 0.261 \\
\cline { 2 - 6 } & Cons & 0.1379 & 0.0590 & 2.34 & 0.019 \\
\hline \multirow{2}{*}{$\Delta \ln (\mathrm{M} 2 / G D P)_{\mathrm{t}-1}$} & $\mathrm{~L} 1$ & -0.1692 & 0.0313 & -5.41 & 0.000 \\
\cline { 2 - 6 } & Cons & 0.0311 & 0.0084 & 3.70 & 0.000 \\
\hline \multirow{2}{*}{$\Delta \ln (\mathrm{FDI} / G D P)_{\mathrm{t}-1}$} & L1 & 0.1393 & 0.0071 & 3.18 & 0.041 \\
\cline { 2 - 6 } & Cons & 0.1271 & 0.2127 & 0.60 & 0.550 \\
\hline \multirow{2}{*}{$\Delta \ln (\mathrm{DF} / G D P)_{\mathrm{t}-1}$} & L1 & 0.2931 & 0.0064 & 4.42 & 0.000 \\
\cline { 2 - 6 } & Cons & 0.0149 & 0.0554 & 0.27 & 0.788 \\
\hline \multirow{2}{*}{$\Delta \ln (\mathrm{DD} / \mathrm{GDP})_{\mathrm{t}-1}$} & L1 & 0.1703 & 0.0098 & 2.55 & 0.076 \\
\cline { 2 - 6 } & Cons & 0.0276 & 0.0295 & 0.93 & 0.350 \\
\hline \multirow{2}{*}{$\Delta(\mathrm{CPDF} / G D P)_{\mathrm{t}-1}$} & L1 & 0.0862 & 0.0894 & 2.30 & 0.081 \\
\cline { 2 - 6 } & Cons & -0.0617 & 0.0777 & -0.79 & 0.427 \\
\hline & L1 & 0.0731 & 0.0218 & 3.33 & 0.048 \\
\cline { 2 - 6 } & Cons & 0.0753 & 0.0595 & 1.26 & 0.206 \\
\hline
\end{tabular}

Table 11 below represents VEC results when Johansen normalization is imposed. The results show that all variables are significant except for credit to private sector by foreign banks. This indicate that in economic growth of Tanzania domestic banks deposits and credit to private sector by domestic banks they play a great role as they are significant at $1 \%$ as opposed to deposits in foreign banks which are significant at 5\%. Foreign Direct Investment as share of GDP is also found to be significant at $1 \%$ and broad money as share of GDP found to be significant at $5 \%$ level.

Table 11: VEC Results when Johansen Normalization Restrictions is imposed

\begin{tabular}{|l|c|c|c|c|}
\hline Variable & Coefficients & Std Error & Z-statistics & P-Value \\
\hline $\ln (\mathrm{M} 2 / G D P)$ & -2.9620 & 1.4448 & -2.05 & 0.040 \\
\hline $\ln (\mathrm{FDI} / G D P)$ & -1.5904 & 0.6085 & 2.01 & 0.009 \\
\hline $\ln (\mathrm{DD} / \mathrm{GDP})$ & 12.9844 & 2.8678 & 4.53 & 0.000 \\
\hline $\ln (\mathrm{DF} / \mathrm{GDP})$ & -2.8331 & 1.4091 & -2.01 & 0.044 \\
\hline $\ln (\mathrm{CPD} / \mathrm{GDP})$ & 3.9181 & 0.9906 & 3.96 & 0.000 \\
\hline $\ln (\mathrm{CPF} / \mathrm{GDP})$ & -0.1172 & 0.5680 & 0.21 & 0.837 \\
\hline Constant & 10.1544 & 1.8648 & 3.15 & 0.00 \\
\hline
\end{tabular}




\section{Concluding Remarks}

This paper investigated empirically impact of financial development on economic growth in Tanzania. VEC model estimates found that the four variables that were structured to give that analysis namely, Customer Deposits in foreign banks and Customer Deposits in local banks as a share of GDP, Credit to Private Sector by domestic banks and Credit to Private Sector by foreign banks ratio to GDP all have significant impact on GDP both in short-run and long-run. When Johansen normalization is imposed, the model also predicted that in the short-run customers' deposits and credit to private sectors by domestic banks have significant impacts by $1 \%$ as opposed to foreign banks deposits that was significant at $5 \%$ and credit to private sector by foreign banks was insignificant. The results also show that the selected financial variables have long-run relationship with GDP growth. This paper provides evidence that financial development leads to growth. Therefore in order for this emerging economy to benefit from growth, it is suggested that further initiation of policies and regulations to reform financial systems is required. This could be done by way of enhancing efficiency and technological innovations to ensure prudential regulation and management in the financial sector, and expansion of the capital market to be more liquid and raise long-term funds for corporate bodies and accessing of credit by large number of the economic agents. It is further recommended that development of microfinance institutions should be given priority in the country. Development of sustainable microfinance institutions will ensure credit accessibility to the rural areas to initiate viable startup businesses and existing ones to increase income level and reduce poverty, as credit to private sector found to have significant impact on growth of the economy. For the issues of extending credit to private sector, the government should encourage financial institutions, particularly commercial banks, to lend to productive sectors in the country such as agricultural sector which accounts for about $60 \%$ of the GDP so as to promote economic growth. It is imperative that commercial banks also reduce their cost of lending so as to stimulate investment and hence promote economic growth. In other words, the government should gear its policies towards strengthening and developing financial sector in country. Some measure such as government deposits to the strategic commercial banks will provide much needed fuel in driving economic growth in the long-run as these deposits will be extended to the private sector as credits in order to facilitates investments in much needed project in the economy.

\section{References}

Abu-Bader, S., and Abu-Qarn, A.M. (2008) "Financial Development and Economic Growth: Empirical Evidence from MENA Countries", Review of Development Economics, 12(4): 803-817.

Adusei, M. (2012) “Financial Development and Economic Growth: is Schumpeter Right?" British Journal of Economics, Management \& Trade, 2(3): 265-278.

Adusei, M. (2013) "Financial Development and Economic Growth: Evidence from Ghana”, International Journal of Business and Finance Research, 7(5): 61-76.

Agbetsiafa, D.K. (2004) "The Finance Growth nexus: Evidence from Sub-Saharan Africa", Savings and Development, 28(3): 271-288. 
INTERNATIONAL JOURNAL OF ACADEMIC RESEARCH IN BUSINESS AND SOCIAL SCIENCES Vol. 8, No. 8, August 2018, E-ISSN: 2222-6990 @ 2018 HRMARS

Akinlo, A and Egbetunde, T (2010) "Financial Development and Economic Growth: The Experience of 10 Sub-Saharan African Countries Revisited", The Review of Finance and Banking, 2(1): 17-28.

Akpansung, A. O. and Babalola, S. J. (2012). "Banking Sector Credit and Economic Growth in Nigeria: An Empirical Investigation", CBN Journal of Applied Statistics, 2(2):51-62.

Andrei, D and Liviu, A (2015) "Vector Error Correction Model in Explaining the Association of Some Macroeconomic Variables in Romania", Procedia Economics and Finance, 22:568-576.

Ang, J.B. (2008) "Survey of Recent Developments in the Literature of Finance and Growth", Journal of Economic Surveys, 22(3): 536-576

Al-Malkawi, H.A.N., Marshadeh.A. and Abdullah, N. (2012) "Financial Development and Economic Growth in the UAE: Empirical assessment using ARDL approach to Cointegration", International Journal of Economics and Finance, 4(5): 105-117

Arcand. J., Berkes, E. and Panizza, U. (2012) "Too Much Finance?", International Monetary Fund. Research Department 12/161

Atindehou, R.B., J.P. Gueyie and E.K. Amenounve (2005) "Financial Intermediation and Economic Growth: Evidence from Western Africa", Applied Financial Economics, 15 (11): 77-790.

Ayadi, R., Ben-Naceur, S., De Groen,W. P., and Arbak E., (2013) "Financial Development, Bank Efficiency and Economic Growth Across the Mediterranean", MEDPRO Technical Report.

Bagehot, W. (1873) Lombard Street: Description of the Money Market, IL: Richard D. Irwin, 1962 Edition

Baliamoune-Lutz, M. (2008) "Financial Development and Income", International Advances in Economic Research, 14: 422-432.

Baltagi, B.H., Demetriades, P.O., and Law, S.L. (2009) "Financial Development and Openness: Evidence from Panel Data", Journal of Development Economics, 89(2): 285-296.

Banerjee, A., Dolado, J. J., Galbraith, J. W., and Hendry, D. F. (1993) Cointegration, Error Correction, and Econometric Analysis of Non-stationary Data, Oxford: Oxford University Press.

Ben Naceur, S., S. Ghazouani and M. Omran (2008) “Does Stock Market Liberalization spur Financial and Economic Development in the MENA Region?", Journal of Comparative Economics, 36(4): 673-693.

Bittencourt, M. (2012) "Financial Development and Economic Growth in Latin America: is 
INTERNATIONAL JOURNAL OF ACADEMIC RESEARCH IN BUSINESS AND SOCIAL SCIENCES Vol. 8, No. 8, August 2018, E-ISSN: 2222-6990 C 2018 HRMARS

Schumpeter Right?", Journal of Policy Modeling, 34(3): 341-355.

Brasoveanul, L. O., Dragota V., Catarama D., and Semenescu, A. (2010) "Correlations between Capital Market Development and Economic Growth: The Case of Romania", Journal of Applied Quantitative Methods, 3(1): 46-75.

Buffie, E. F. (1984) "Financial Repression, the New Structuralists, and Stabilization Policy in Semi-industrialized Economics", Journal of Development Economics, 14(3): 305-22.

Cavaliere, G., Rahbek, A., and Taylor, R. (2007) "Testing for Co-integration in Vector Autoregressions with Non-stationary volatility", Granger Centre Discussion Paper, $07 / 02$

Dickey, D. and Fuller, W. (1981) "Likelihood Ratio Statistics for Autoregressive Time Series with a Unit Root", Econometrica, 49(4): 1057-1072.

Donwa, P. and Odia, J. (2010) "An Empirical Analysis of the Impact of the Nigerian Capital Market on Her Socio-economic Development", Journal of Social Sciences, 24(2): 135142.

Eita J.H., and Jordaan A.C. (2010) "A Causality Analysis between Financial Development and Economic Growth for Botswana", The African Finance Journal, 12(1): 72-89.

Engle, R. F. and Granger, C. W. J. (1987) "Cointegration and Error Correction: Representation, Estimation, and Testing", Econometrica, 55(2): 252-276.

Esso, L.J. (2010) "Re-examining the Finance-Growth nexus: Structural Break, threshold Cointegration and Causality evidence from the Ecowas", Journal of Economic Development, 35(3): 57-79.

Ghirmay, T. (2004) "Financial Development and Economic Growth in Sub-Saharan African Countries: Evidence from Time Series Analysis", African Development Review, 16(3): 415-432.

Goldsmith, R.W. (1969) Financial Structure and Development, New Haven, CT: Yale University Press.

Goodhart, C. A. E. (2004) Financial Development and Growth: Explaining the Links, New York: Palgrave Macmillan.

Graff, M. (2005) "Socio-Economic Factors and the Finance-Growth Nexus", The European Journal of Finance, 11(30): 183-205

Gujarati, D.N (2009) Basic Econometrics, New Delhi: Tata McGraw-Hill Education. 
INTERNATIONAL JOURNAL OF ACADEMIC RESEARCH IN BUSINESS AND SOCIAL SCIENCES

Vol. 8, No. 8, August 2018, E-ISSN: 2222-6990 C 2018 HRMARS

Herwartz, H. and Walle, Y. M. (2014) "Determinants of the Link between Financial and Economic Development: Evidence from a Functional Coefficient Model", Economic Modelling, 37(2): 417-427

Hicks, J. R. (1969) A Theory of Economic History, Oxford: Clarendon Press.

Jalil, A., Ma, Y. and Naveed, A. (2010) "The Finance-Fluctuation Nexus: Further Evidence from Pakistan and China", International Research Journal of Finance and Economics, 14: 212-231

Johansen, S. (1988) "Statistical Analysis of Cointegrating Vectors", Journal of Economic Dynamics and Control, 12(1-2): 231-254.

Johansen, S. and Juselius, K. (1990) "Maximum Likelihood Estimation and Inference on Cointegration with Application to Demand for Money", Oxford Bulletin of Economics and Statistics, 52(2): 169-210.

Kar, M., Nazlioglu, S., and Agir, H. (2011) "Financial Development and Economic Growth nexus in the MENA countries: Bootstrap Panel Granger Causality Analysis", Economic Modelling, 28( 1-2): 685-693.

Khandker, S. R. (2005) “Microfinance and Poverty: Evidence Using Panel Data from Bangladesh", The World Bank Economic Review, 19(2): 263-286.

King, R., and Levine R. (1993) "Finance and Growth: Schumpeter might be Right", Quarterly Journal of Economics, 108(3): 717-737.

Levine, R. and Zervos, S. (1998) "Stock Markets, Banks and Economic Growth", American Economic Review, 88(3): 537-558.

Levine R. (2003) “More on Finance and Growth: More Finance, More Growth?" Federal Reserve Bank of St Louis.

Levine, R. (2005) "Finance and Growth: Theory and Evidence." Handbook of Economic Growth, Amsterdam, Netherlands, Elsevier, Chapter 12, 1(1), 865-934.

Liang, Q., and Teng J.Z. (2006) "Financial Development and Economic Growth: Evidence from China", China Economic Review, 17(4): 395-411.

Lucas, R.E. Jr. (1988) "On the Mechanics of Economic Development", Journal of Monetary Economics, 22: 3-42.

McKinnon, R.I. (1973) Money and Capital in Economic Development, Washington, D.C: Brookings Institution Press. 
INTERNATIONAL JOURNAL OF ACADEMIC RESEARCH IN BUSINESS AND SOCIAL SCIENCES Vol. 8, No. 8, August 2018, E-ISSN: 2222-6990 C 2018 HRMARS

Menyah, K., Nazlioglu, S. and Wolde-Rufael, Y. (2014) "Financial Development, Trade Openness and Economic Growth in African Countries: New insights from a Panel Causality Approach", Economic Modeling, 37: 386-394

Naceur, S. B. and Ghazouani, S. (2007) "Stock Markets, Banks, and Economic Growth: Empirical evidence from the MENA region", Research in International Business and Finance, 21(2): 297-315

Ndako, U.B. (2010) “Financial Development and Economic Growth: Evidence from Nigeria:' The IUP Journal of Financial Economics, 8(4):37-59.

Nowbutsing, B. M. (2009) "Stock Market Development And Economic Growth: The Case Of Mauritius", International Business \& Economics Research Journal, 8(2): 77-88.

Odhiambo, N.M. (2007) "Supply-leading versus demand-following hypothesis: empirical evidence from three SSA countries", African Development Review, 19(2): 257-280.

Odhiambo, N.M. (2009) "Finance-Growth nexus and Inflation Dynamics in Kenya: an empirical investigation", Savings and Development, 33(1): 7-25.

Odhiambo, N.M. (2010) "Finance-Investment-Growth nexus in South Africa: an ARDL-bounds Testing Procedure", Economic Change Restructure, 43(3): 205-219.

Pradhan, R. P., Dasgupta, P. and Samadhan, B. (2013) "Finance Development and Economic Growth in BRICS: A Panel Data Analysis", Journal of Quantitative Economics, 11(12): 308-322

Quartey, P., and Prah F. (2008) "Financial Development and Economic Growth in Ghana: is there a Causal Link?", The African Finance Journal, 10(1): 28-54.

Rioja, F., and Valev N. (2004) "Does one size fit all? A Re-examination of the Finance and Growth relationship", Journal of Development Economics, 74: 429-47.

Robinson, J. (1952) The Rate of Interest and Other Essays, London: MacMillan.

Rousseau, P. L. and Watchel, P. (2011) "What is happening to the Impact of Financial deepening on Economic Growth?" Economic Inquiry, 49(1): 276-288.

Schumpeter J. A. (1911) The theory of Economic Development, Cambridge, MA: Harvard University Press.

Schumpter, J. A. (1934) "Theorie der Wirtschaftlichen Entwickiung [The theory of economic development]', Leipzig: Dunker\& Humblot, 1912; translated by Redvers Opie. Cambridge, MA: Harvard Univesrity Press 
INTERNATIONAL JOURNAL OF ACADEMIC RESEARCH IN BUSINESS AND SOCIAL SCIENCES Vol. 8, No. 8, August 2018, E-ISSN: 2222-6990 C 2018 HRMARS

Shaw, E.S. (1973) Financial Deepening in Economic Development, New York: Oxford University Press.

Shen, C. H., and Lee, C. C., (2006) "Same Financial Development yet different Economic Growth- why?, Journal of Money, Credit and Banking, 38(7): 1907-1944.

Stern, N. (1989) “The Economics of Development: A Survey", Economic Journal, 99(397): 597685.

Tran, A. T. (2008) "Financial Development and Economic Growth in the Case of Vietnam", Journal of International Business and Economics, 8(2): 135-153.

Van Wijnbergen, S. (1983) "Credit Policy, Inflation and Growth in a Financially Repressed Economy", Journal of Development Economics, 13(1-2): 45-65.

Vazakidis, A. and Adamopouslos, A. (2009). “Credit Market Development and Economic Growth", American Journal of Economics and Business Administration, 1(1): 34-40

Wu, J., Hou, H. and Cheng, S. (2010) "The Dynamic Impacts of Financial Institutions on Economic Growth: Evidence from the European Union", Journal of Macroeconomics, 32(3): 879-891.

Xu, Z. (2000) "Financial Development, Investment, and Economic Growth", Economic Inquiry, 38(2): 331-344

Zang, H., and Kim Y.C. (2007) “Does Financial Development precede Growth? Robinson and Lucas might be Right", Applied Economics Letters, 14(1): 15-19.

Zivengwa, T., Mashika, J., Bokosi, K., Makova, T. (2011) “Stock Market Development and Economic Growth in Zimbabwe", International Journal of Economic Finance, 3(5): 140-150. 